\title{
Implementasi Program Adiwiyata Mandiri dalam Menanamkan Karakter Peduli Lingkungan
}

\author{
Sri Nuzulia, Sukamto, Agus Purnomo \\ Universitas Negeri Malang \\ email: sri.nuzulia0404@gmail.com
}

Naskah diterima: 14 Mei 2019, direvisi: 9 Oktober 2019, disetujui: 1 November 2019

\begin{abstract}
Adiwiyata is an effort from the government to create a generation of people who are aware and have a sense of love and responsibility towards the environment. The adiwiyata program bas become the flagship program implemented in SMP Negeri 15 Malang, as a basic curriculum in the learning and learning process based on environmental education that contains environmental care characters which are shown by respect for nature. The purpose of this study was to analyze the implementation of environmental care characters in SMP Negeri 15 Malang students. This study uses a qualitative approach to the type of descriptive research. Data collection techniques in research are interviews, observation, and documentation. The results showed that the adiwiyata program at SMP Negeri 15 Malang was implemented through extra-curricular activities and mandatory adiviyata days, where students could care for the school environment to foster environmental attitudes and insights, while at the same time caring for the environment.
\end{abstract}

Keywords: Adiwiyata, Implementation, Character Caring For The Environment

\begin{abstract}
Abstrak
Adiwiyata merupakan upaya dari pemerintah untuk menciptakan generasi bangsa yang sadar dan memiliki rasa cinta dan tanggung-jawab terhadap lingkungan. Program adiwiyata menjadi program unggulan yang diterapkan di SMP Negeri 15 Malang, yakni sebagai kurikulum dasar dalam proses belajar dan pembelajaran berlandaskan pendidikan lingkungan hidup yang memuat karakter peduli lingkungan yang ditunjukkan dengan adanya penghargaan terhadap alam. Tujuan penelitian ini adalah untuk menganalisis implemetasi karakter peduli lingkungan pada siswa SMP Negeri 15 Malang. Penelitian ini menggunakan pendekatan kualitatif dengan jenis penelitian deskriptif. Teknik pengumpulan data dalam penelitian adalah wawancara, observasi, dan dokumentasi. Hasil penelitian menunjukkan bahwa program adiwiyata di SMP Negeri 15 Malang diimplementasikan melalui kegiatan ekstra kurikuler dan hari wajib adiwiyata, di mana para siswa dapat merawat lingkungan sekolah guna menumbuhkan sikap dan wawasan lingkungan, sekaligus memiliki kepedulian terhadap lingkungan.
\end{abstract}

Kata Kunci: Adiwiyata, Implementasi, dan Karakter Peduli Lingkungan. 


\section{PENDAHULUAN}

Aktivitas manusia adalah salah satu unsur yang menentukan kualitas lingkungan hidup. Banyaknya kerusakan lingkungan yang diakibatkan oleh faktor antropogenik mendorong adanya upaya untuk melakukan perbaikan lingkungan. Indonesia menjadi salah satu negara yang juga menaruh perhatian dalam upaya pengelolaan lingkungan. Hal ini dibuktikan dengan adanya Undang-Undang Nomor 32 Tahun 2009 tentang Perlindungan dan Pengelolaan Lingkungan Hidup yang isinya mencakup perencanaan, pemanfaatan, pengendalian, pemeliharaan, sampai pada pengawasan dan penegakan hukum (Kementerian Lingkungan Hidup, 2009)

Perilaku manusia adalah faktor utama yang menyebabkan kerusakan lingkungan secara global. Kerusakan lingkungan disebabkan oleh perilaku peduli lingkungan masih sangat minim, khususnya di Indonesia, salah satu upaya yang dilakukan pemerintah Indonesia untuk meningkatkan perilaku kepedulian lingkungan yaitu dengan mengadakan Pendidikan Lingkungan Hidup (PLH) di dalam dunia pendidikan (Iswari, 2017). Hal ini dibuktikan dengan adanya Undang-Undang Nomor 32 Tahun 2009 tentang Perlindungan dan Pengelolaan Lingkungan Hidup yang isinya mencakup perencanaan, pemanfaatan, pengendalian, pemeliharaan, sampai pada pengawasan dan penegakan hukum (Kementerian Lingkungan Hidup, 2009). Dapat dikatakan bahwa pendidikan lingkungan adalah salah satu upaya untuk memberikan pengetahuan lingkungan di kalangan pelajar sekolah. Hal ini ditunjukkan dengan asumsi bahwa jika pengetahuan tentang lingkungan meningkat, maka perilaku peduli lingkungan juga meningkat dan akan mengurangi kerusakan lingkungan di masa yang akan datang.

Pendidikan lingkungan hidup di Indonesia disalurkan lewat kurikulum ketrampilan 2013 yang mengedepankan pendidikan karakter, di dalam pendidikan karakter tersebut terdapat karakter peduli lingkungan atau dapat disebut pendidikan karakter adiwiyata. Program Adiwiyata dapat dilaksanakan secara optimal sejak tahun 2010 seiring dengan adanya kebijakan baru yang menggantikan kebijakan sebelumnya antara Menteri Lingkungan Hidup dan Menteri Pendidikan Nasional melalui kesepakatan bersama. Hal ini kemudian dikuatkan lagi dengan adanya Peraturan Menteri (Permen) Lingkungan Hidup Nomor 5 Tahun 2013 tentang Pedoman Pelaksanaan Program Adiwiyata (Kementerian Lingkungan Hidup Republik Indonesia, 2013). Tujuan dari Program Adiwiyata berdasarkan pada Permen tersebut yaitu untuk mewujudkan sekolah yang peduli dan berbudaya lingkungan, pelaksanaannya berdasarkan tiga prinsip yaitu edukatif, partisipatif, dan berkelanjutan.

Keberadaan Program Adiwiyata ini belum dapat menjamin sepenuhnya peningkatan kepedulian lingkungan di kalangan pelajar, Pernyataan tersebut didukung hasil penelitian terdahulu mengenai Implementasi Adiwiyata. Penelitian pertama oleh Landriany (2014) dalam Jurnal Kebijakan dan Pengembangan Pendidikan yang berjudul "Implementasi Kebijakan Adiwiyata dalam Upaya Mewujudkan Pendidikan Lingkungan Hidup di SMA Kota Malang" dengan hasil penelitiannya bahwa Adiwiyata belum berhasil dilaksanakan di SMA Kota Malang. Hal ini dikarenakan beberapa faktor, antara lain: beberapa siswa masih belum paham mengenai konsep sekolah berwawasan lingkungan, beberapa diantaranya masih tidak peduli dengan kondisi lingkungan, kurangnya peran serta masyarakat, dan kurangnya antusias penerapan PLH di kalangan guru dan karyawan sekolah.

Pelaksanaan Pendidikan Lingkungan Hidup di sekolah-sekolah agar mendapat hasil yang lebih baik perlu dicermati dan dimonitoring oleh seluruh pemangku kepentingan. Karakter yang akan dibentuk dan dikembangkan dari hasil pembelajaran Pendidikan Lingkungan Hidup itu perlu dimonitoring dan dievaluasi agar tujuan karakter yang ingin dicapai betul akan terealisasi (Badan Lingkungan Hidup, 2014).

Kedua, Penelitian terdahulu oleh Bahrudin (2017) dalam jurnal pendidikan geografi dengan judul "Pelaksanaan Program Adiwiyata dalam Mendukung Pembentukan Karakter Peduli Lingkungan di SMA Negeri 4 Pandeglang" 
berdasarkan hasil observasi, guru memberikan untuk mengintegrasikan pendidikan lingkungan hidup dalam setiap mata pelajaran di sekolah. Integrasi pendidikan lingkungan hidup dilakukan di setiap mata pelajaran di sekolah. Mata pelajaran seperti Matematika, Kimia, Ekonomi dan lain sebagainya. Salah satu contoh integrasi Pelajaran Matematika dengan Lingkungan Hidup adalah mengukur jarak tanaman di sekolah agar terlihat rapi. Mata pelajaran Kimia, guru mengajarkan agar bahan-bahan kimia atau zat-zat yang berbahaya tidak boleh dibuang sembarangan, dikarenakan dapat merusak lingkungan. Oleh karena itu, pembiasaan Pendidikan Lingkungan Hidup dan implementasinya dalam mata pelajaran sehari-hari akan membentuk suatu karakter yang peduli terhadap lingkungannya.

Perbedaan penelitian yang dikaji ini dengan kedua penelitian di atas terletak pada lokasi dan fokus subjek penelitiannya. Penelitian oleh Landriany (2014) berfokus pada implementasi pendidikan lingkungan hidup di kota Malang dan penelitian oleh Bahrudin (2017) berfokus pada penerapan pembentukan karakter peduli lingkungan di SMA Negeri 4 Pandeglang. Berdasarkan kedua penelitian tersebut, belum ada yang membahas mengenai fokus penelitian terhadap implementasi Adiwiyata Mandiri dan lokasi penelitian di SMP Negeri 15 Malang.

Program sekolah Adiwiyata memiliki peran strategis dalam peningkatan kepedulian lingkungan hidup yang sedang mengalami kemerosotan di abad ke-21 ini. Dengan tujuan dan peran tersebut, kontribusi Program Adiwiyata terhadap pembentukan karakter peduli lingkungan sangat mungkin terwujud. (Kementerian Lingkungan Hidup Republik Indonesia, 2013) program sekolah Adiwiyata memiliki empat aspek di dalam pelaksanaanya, antara lain adalah aspek kebijakan berwawasan lingkungan, aspek kurikulum sekolah berbasis lingkungan, aspek kegiatan berbasis partisipatif dan aspek pengelolaan sarana pendukung ramah lingkungan. Sesuai dengan tujuan dari Program Adiwiyata diharapkan mampu mewujudkan warga sekolah yang bertanggung jawab dalam upaya perlindungan dan pengelolaan lingkungan hidup melalui tata kelola sekolah yang baik untuk mendukung pembangunan berkelanjutan.

Kota Malang memiliki jumlah sekolah Adiwiyata terbanyak di Indonesia, tahun 2017 sebanyak 173 sekolah dasar SD dan SMP di Kota Malang sudah berstatus sekolah Adiwiyata. Jumlah 173 sekolah adalah gabungan dari sekolah Adiwiyata tingkat kota, provinsi, nasional, dan mandiri, SMP Negeri 15 Malang menjadi salah satu sekolah yang membanggakan Jawa Timur dan Kota Malang. SMP Negeri 15 Malang yang terletak di perbatasan kota dan kabupaten Malang, lebih tepatnya di Kelurahan Pisang Candi, Kecamatan Sukun, Kota Malang membanggakan Jawa Timur dan kota Malang lewat prestasi, mendapatkan kehormatan menjadi Adiwiyata mandiri dari sebanyak 113 sekolah seluruh Indonesia yang mengikuti seleksi Adiwiyata mandiri (Dinas Pendidikan Kota Malang, 2017).

Keberhasilan SMP Negeri 15 Malang meraih Adiwiyata mandiri merupakan hasil perjuangan dan kerja keras dari seluruh warga sekolah yang berpartisipasi dalam pelaksanaan tata kelola pendidikan Adiwiyata. SMPN 15 Malang memiliki tiga prinsip untuk membumikan semangat cinta peduli lingkungan yaitu edukatif, partisipatif dan berkelanjutan. Edukatif adalah proses dimana memberikan wawasan mengenai kepedulian terhadap lingkungan, partisipatif adalah proses dimana semua warga sekolah ikut andil dalam penerapan kepedulian terhadap lingkungan dan diharapkan proses penerapan kepedulian ini dapat berkelanjutan dan memberikan dampak yang positif untuk masa depan SMP Negeri 15 Malang.

Pelaksanaan kebijakan berwawasan lingkungan di sekolah dilaksanakan sesuai dengan buku Panduan Adiwiyata. Pengembangan KTSP (Kurikulum Tingkat Satuan Pendidikan) sekolah telah termuat upaya kebijakan untuk perlindungan dan pengelolaan lingkungan hidup. Hal tersebut ditandai dengan visi dan misi sekolah sesuai dengan nilai-nilai dan upaya perlindungan dan pengelolaan lingkungan hidup yaitu pada visi sekolah salah satunya terwujudnya lingkungan sekolah dan masya- 
rakat sekolah yang peduli dan berbudaya lingkungan dengan didukung misi membangun karakter warga sekolah yang dapat melestarikan lingkungan. Visi dan misi menjadi patokan tata kelola sekolah dalam menjalankan programprogram kegiatan untuk siswa dengan penerapan visi dan misi yang berbasis peduli lingkungan dapat menghasilkan budaya pada warga sekolah terhadap sikap peduli lingkungan.

Alasan peneliti memilih implemetasi karakter peduli lingkungan siswa di SMP Negeri 15 Malang ini karena, Program Adiwiyata merupakan program unggulan yang diterapkan sekolah sebagai kurikulum dasar belajar dan pembelajaran berlandaskan pendidikan lingkungan hidup. Berdasarkan alasan tersebut peneliti ingin mengetahui apakah penerapan Program Adiwiyata Mandiri memberikan dampak bagi pembentukan karakter peduli lingkungan siswa SMP Negeri 15 Malang.

\section{METODE PENELITIAN}

Fokus penelitian ini adalah Implementasi Program Adiwiyata Mandiri Dalam Menanamkan Karakter Peduli Lingkungan Siswa SMP Negeri 15 Malang. Maka untuk memperoleh dan mengumpulkan data, peneliti mengkaji penelitian ini menggunakan pendekatan kualitatif. Menurut metode kualitatif juga berarti metode penelitian yang hasil datanya ditampilkan dalam model verbal dan tidak menggunakan teknik statistik (Ibnu, 2003). Penelitian ini menunjukan peneliti juga sebagai instrumen utama yang harus hadir dalam penelitian lapangan, karena peneliti sebagai perencana, memilih informan, pengumpul data, menafsirkan data, dan menarik kesimpulan yang ada dalam lapangan, sehingga didapatkan hasil yang detail dan tanpa unsur yang dibuatbuat.

Peneliti menggunakan jenis penelitian deskriptif. Penelitian deskriptif bertujuan untuk mendeskripsi secara sistematis, faktual, dan akurat terhadap suatu daerah tertentu mengenai berbagai sifat dan faktor tertentu (Santoso, 2007). Untuk memperoleh data yang lebih spesifik digunakan desain deskriptif penelitian studi kasus sehingga didapatkan gambaran detail tentang implementasi Program Adiwiyata di SMPN 15 Malang. Penelitian ini dilaksanakan bertempat di SMP Negeri 15 Malang yang beralamatkan di Jl. Bukit Dieng T/8. Kelurahan Pisang Candi, Kecamatan Sukun, Kota Malang.

Data penelitian didapatkan melalui sumber primer dan sekunder, sumber primer diperoleh dari informan kunci dan pendukung, informan kunci meliputi siswa duta lingkungan dan siswa regular untuk informan pendukung meliputi guru pembina Adiwiyata dan Wakil Kepala Kurikulum SMP Negeri 15 Malang sedangkan sumber sekunder diperoleh melalui buki-bukti hasil kegiatan Adiwiyata di SMP Negeri 15 Malang. Teknik pengumpulan data dalam penelitian ada tiga, yaitu wawancara, observasi, dan dokumentasi. Aktivitas menganalisis data menggunakan analisis data yaitu pengumpulan data, reduksi data, penyajian data, dan kesimpulan atau verifikasi (Miles, 2014). Tahap-tahap penelitian yang dilakukan yaitu tahap persiapan, tahap penyususnan rancanagan penelitian, tahap perizinan, tahap penyusunan instrument penelitian, tahap pelaksanaan, tahap pengumpulan data, mengolah data, analisis data, penarikan kesimpulan, dan yang terakhir tahap pelaporan.

\section{HASIL DAN PEMBAHASAN}

Karakter dimaknai sebagai cara berfikir dan berperilaku yang khas tiap individu untuk hidup dan bekerja sama, baik dalam lingkup keluarga, masyarakat, bangsa, dan negara. Individu yang berkarakter baik adalah individu yang dapat membuat keputusan dan siap mempertanggungjawabkan setiap akibat keputusannya (Mumpuni, 2016). Karakter terdiri atas nilai-nilai kebajikan yang digunakan sebagai pedoman dalam berperilaku. Karakter sebagai kepribadian yang terbentuk dari kebajikan digunakan sebagai landasan dalam berpikir, bersikap, dan bertindak. Apabila kebajikan digunakan dalam segala hal, maka tindakan tidak akan melanggar norma atau aturan.

Karakter merupakan nilai dasar perilaku yang menjadi acuan tata nilai interaksi antar manusia, karakter akan terbentuk melalui 
perilaku yang dilakukan secara berulang-ulang (Yusinta, 2016). Pembentukan karakter sejak dini bertujuan agar nilai-nilai karakter yang ingin dibangun terekam dengan baik di benak peserta didik. Pendidikan karakter merupakan segala sesuatu yang dilakukan guru untuk mempengaruhi karakter peserta didik.

Mengingat karakter penting untuk membangun kepribadian seseorang dan bangsa, pemerhati dan pelaku pendidikan menawarkan berbagai solusi, salah satunya yaitu pendidikan karakter. Dasar pendidikan di Indonesia menggunakan Kurikulum 2013 yang menerapkan pendidikan karakter sebagai dasar dari proses belajar dan pembelajaran (Mumpuni, 2016). Kompetensi belajar dan pembelajaran yang harus dicapai setiap tingkatannya, meliputi sikap spiritual, sikap sosial, pengetahuan, dan keterampilan. Separuh dari kompetensi yang harus dicapai yaitu kompetensi spiritual dan kompetensi sosial berkaitan dengan nilai-nilai karakter. Oleh sebab itu, dapat dikatakan bahwa Kurikulum 2013 sebagai kurikulum yang menekankan pada pengembangan karakter siswa.

Pendidikan karakter dapat didefinisikan sebagai pendidikan yang mengembangkan karakter yang baik dari peserta didik dengan mempraktikkan dan mengajarkan nilai-nilai moral dan pengambilan keputusan yang baik dalam hubungan dengan sesama manusia maupun dalam hubungannya dengan lingkungannya. Menurut Samani (2012) dalam buku "Konsep dan Model Pendidikan Karakter" mengatakan pendidikan karakter didefinisikan sebagai setiap rencana sekolah, yang dirancang bersama lembaga masyarakat lain untuk membentuk secara langsung sistematis perilaku orang muda dengan mempengaruhi secara eksplisit nilai-nilai kepercayaan non-relativistik (diterima luas) yang dilakukan secara langsung menerapkan nilai-nilai tersebut.

Pembangunan karakter harus menyatu dan menjadi bagian yang terpadu dalam proses pembelajaran yang tidak berdiri sendiri secara terpisah. Hal tersebut sebagaimana diamanatkan UU No 20 Tahun 2003 Tentang Sistem Pendidikan Nasional pada pasal 3 yang menyebutkan bahwa pendidikan nasional berfungsi mengembangkan kemampuan dan membentuk karakter serta peradaban bangsa yang bermartabat dalam rangka mencerdaskan kehidupan bangsa (Ardianti, 2017). Dapat dikatakan bahwa pendidikan karakter harus dikembangkan secara utuh dalam bingkai Sistem Pendidikan Nasional dalam rangka mencapai tujuan Pendidikan Nasional.

Pendidikan karakter dapat pula dimaknai sebagai upaya yang terencana untuk menjadikan peserta didik mengenal, peduli, dan menginternalisasi nilai-nilai sehingga peserta didik berperilaku yang baik. Pendidikan karakter juga dapat dimaknai sebagai suatu sistem penanaman nilai-nilai karakter kepada warga sekolah yang meliputi komponen pengetahuan, kesadaran atau kemauan, dan tindakan untuk melaksanakan nilai-nilai tersebut baik terhadap Tuhan Yang Maha Esa, diri sendiri, sesama, lingkungan, maupun kebangsaan sehingga menjadi individu yang berperilaku baik. Karakter peduli lingkungan merupakan salah satu karakter yang wajib diimplementasikan di setiap jenjang pendidikan.

Manusia dan lingkungan hidup terdapat hubungan yang dinamis. Perubahan dalam lingkungan hidup akan menyebabkan perubahan dalam perilaku manusia untuk menyesuaikan diri dengan lingkungan yang baru, perubahan dalam perilaku manusia ini kemudian menyebabkan perubahan dalam lingkungan hidup. Menurut Sriyanto (2007) dengan adanya hubungan dinamis sejajar antara manusia dengan lingkungan hidup dapat dikatakan "hanya dalam lingkungan hidup yang baik, manusia dapat berkembang secara maksimal, dan hanya dengan manusia yang baik lingkungan hidup dapat berkembang kearah yang optimal". Karena itu sangat jelas bahwa penting untuk melakukan pembinaan lingkungan hidup.

Peduli lingkungan didefinisikan sebagai sikap dan tindakan yang selalu berupaya mencegah kerusakan pada lingkungan alam di sekitarnya dan mengembangkan upaya-upaya untuk memperbaiki kerusakan alam yang sudah terjadi (Iswari, 2017). Dapat dikatakan karakter peduli lingkungan yaitu suatu sikap yang dimiliki oleh seseorang yang berupaya untuk memperbaiki dan mengelola lingkungan sekitar 
secara benar sehingga lingkungan dapat dinikmati secara terus menerus tanpa merusak keadaannya, serta menjaga dan melestarikan sehingga ada manfaat yang berkesinambungan. Keputusan Menteri Pendidikan Nasional Republik Indonesia (2010) mengemukakan hasil diskusi dan sarasehan tentang "Pendidikan Budaya dan Karakter Bangsa" menghasilkan "Kesepakatan Nasional Pengembangan Pendidikan Budaya dan Karakter Bangsa" untuk berbagai wilayah Indonesia yang terdiri dari 18 nilai sebagai berikut: (1) religius, (2) jujur, (3) toleransi, (4) disiplin, (5) kerja keras, (6) kreatif, (7) mandiri, (8) demokratis, (9) rasa ingin tahu, (10) semangat kebangsaan, (11) cinta tanah air, (12) menghargai prestasi, (13) bersahabat, (14) cinta damai, (15) gemar membaca, (16) peduli lingkungan, (17) peduli sosial, dan (18) tanggung jawab. Nilai-nilai pendidikan budaya karakter bangsa tersebut memiliki keterkaitan satu sama lain, di sini peneliti lebih memfokuskan pada nilai karakter peduli lingkungan.

Karakter peduli lingkungan merupakan karakter yang wajib diimplementasikan bagi sekolah di setiap jenjang pendidikan. Semua warga sekolah harus mempunyai sikap peduli terhadap lingkungan dengan cara meningkatkan kualitas lingkungan hidup, meningkatkan kesadaran warga sekolah tentang pentingnya peduli lingkungan serta mempunyai inisiatif untuk mencegah kerusakan lingkungan. Bisa dikatakan bahwa pendidikan karakter peduli lingkungan ditanamkan sejak dini kepada siswa sehingga dapat mengelola secara bijaksana sumber daya alam yang ada di sekitar, serta untuk menumbuhkan rasa tanggung jawab terhadap kepentingan generasi penerus yang akan datang. Ketika karakter peduli lingkungan sudah tumbuh menjadi mental yang kuat, maka akan mendasari perilaku seseorang dalam kehidupan sehari-hari.

Karakter peduli lingkungan ditunjukkan dengan adanya penghargaan terhadap alam. penghargaan terhadap alam adalah kesadaran bahwa manusia menjadi bagian alam, sehingga mencintai alam juga mencintai kehidupan manusia. Mencintai lingkungan hidup dan alam haruslah diarahkan agar ada sikap untuk mencintai kehidupan (Vindriyana, 2017). Sikap peduli lingkungan merupakan suatu proses yang bertujuan untuk menciptakan suatu masyarakat dunia yang memiliki kepedulian terhadap lingkungan dan peduli terhadap masalah-masalah yang terkait di dalamnya serta memiliki pengetahuan, motivasi, komitmen, dan keterampilan untuk bekerja, baik secara perorangan maupun kolektif dalam mencari alternatif atau memberi solusi terhadap permasalahan lingkungan hidup yang ada sekarang dan untuk menghindari timbulnya masalahmasalah lingkungan hidup baru. Tujuan pendidikan karakter peduli lingkungan adalah: (1) Mendorong kebiasaan dan perilaku peserta didik yang terpuji dan sejalan dengan pengelolaan lingkungan yang benar, (2) Meningkatkan kemampuan untuk menghindari sifat-sifat yang dapat merusak lingkungan, (3) Memupuk kepekaan peserta didik terhadap kondisi lingkungan sehingga dapat menghindari sifatsifat yang dapat merusak lingkungan, (4) Menanam jiwa peduli dan bertanggung jawab terhadap kelestarian lingkungan (Marsanti, 2014).

Upaya pembentukan dan pengembangan karakter peserta didik, khususnya karakter peduli lingkungan yang dilakukan melalui pembelajaran Pendidikan Lingkungan Hidup. Karakter yang akan dibentuk dan dikembangkan dari hasil pembelajaran Pendidikan Lingkungan Hidup itu perlu dimonitoring dan dievaluasi agar tujuan karakter yang ingin dicapai betul akan terealisasi. Oleh karena itu, pembiasaan Pendidikan Lingkungan Hidup dan implementasinya dalam kegiatan sehari-hari atau perilaku peduli lingkungan akan membentuk suatu karakter yang peduli terhadap lingkungannya atau disebut dengan istilah karakter peduli lingkungan.

Implementasi Program Adiwiyata untuk mewujudkan warga sekolah yang bertanggung jawab dalam upaya perlindungan dan pengelolaan lingkungan hidup melalui tata kelola sekolah yang baik untuk mendukung pembangunan berkelanjutan. Menurut Tim Adiwiyata Tingkat Nasional (2011), Adiwiyata memiliki dua prinsip, yaitu prinsip partisipatif dan berkelanjutan, dengan Indikator Adiwiyata yang meliputi: (1) Pengembangan kebijakan sekolah yang berwawasan lingkungan, (2) Pengembangan kurikulum berbasis lingkungan, 
(3) Pengembangan kegiatan berbasis partisipatif, dan (4) Pengembangan dan pengelolaan sarana pendukung sekolah berbasis lingkungan.

Kurikulum berbasis lingkungan adalah kurikulum yang memuat tentang materi pengelolaan dan perlindungan terhadap lingkungan hidup yang disampaikan dengan berbagai cara dalam upaya memberikan pemahaman tentang lingkungan hidup (Hidayatun, 2016). Menurut Adam (2014) menambahkan kurikulum berbasis lingkungan secara sederhana dapat diimplementasikan dengan cara penyampaian materi lingkungan hidup melalui kurikulum yang beragam variasi untuk memberikan pemahaman tentang lingkungan hidup yang dikaitkan dalam kehidupan sehari-hari. Menurut Murtilaksono (2011) untuk mengimplementasikan pendekatan integrasi, pendidik harus mempertimbangkan berbagai macam sumber ketika menyusun sebuah rencana pembelajaran, pendidik harus menganalisa dan mengumpulkan materi yang sesuai untuk dikembangkan menjadi materi pembelajaran termasuk materi yang dikaitkan dengan alam, manusia dan sosial

Penerapannya di sekolah, Program Adiwiyata harus terintegrasi dengan Kurikulum 2013 melalui pengembangan Kompetensi Dasar (KD), Indikator Pencapaian Kompetensi (IPK) yang kemudian dikembangkan pada Rencana Pelaksanaan Pembelajaran (RPP) semua mata pelajaran yang ada di sekolah tanpa terkecuali. Melalui pengembangan KD, IPK dan RPP inilah pendidikan karakter terutama yang berhubungan dengan kepedulian terhadap pelestarian lingkungan dicantumkan. Selain itu semua media yang ada di lingkungan sekolah juga harus tercantum pada RPP.

Pembentukkan karakter ini memberikan dampak yang signifikan tehadap siswa SMP Negeri 15 Malang karena program Adiwiyata ini dilakukan setiap hari dan menjadi budaya serta rutinitas siswa untuk memulai jam pelajaran menjadikan siswa terbiasa dan tidak ragu-ragu lagi untuk melakukan perilaku peduli lingkungan, perilaku tersebut yang akhirnya berdampak terhadap perilaku keseharian mereka termasuk cara mereka untuk menjaga kesehatannya sendiri.
Implementasi Adiwiyata di SMP Negeri 15 Malang dimulai dari penanaman karakter siswa untuk cinta dan peduli lingkungan juga penambahan kualitas dan kuantitas sarana prasarana sekolah yang ramah lingkungan seperti penambahan biopori, kegiatan penanaman holtikultura, pemilahan sampah dan pemanfaatan sampah. Kegiatan implementasi tersebut dilakukan dengan rutin dan terus berkembang hingga saat ini mendapatkan penghargaan dari Menteri Lingkungan Hidup dan Kehutanan Republik Indonesia dan Menteri Pendidikan dan Kebudayaan Republik Indonesia sebagai sekolah dengan predikat Adiwiyata tingkat Mandiri.

Pembentukan karakter peduli lingkungan yang diterapkan di sekolah diawali dengan sosialisasi, banyak cara dalam sosialisasi terhadap warga sekolah yang terkait dengan contoh, guru pembina Adiwiyata membimbing guru-guru mata pelajaran untuk memasukkan kegiatan lingkungan hidup beruapa teori maupun praktek ke dalam RPP (Rencana Pelaksanaan Pembelajaran) dan sebagai wujud lingkungan hidup yang sehat dan berkelanjutan di lingkungan sekolah diawali dengan adanya karakter peduli lingkungan yang disalurkan lewat tindakan, contoh tindakan dasar yang dilakukan siswa dalam menerapkan karakter peduli lingkungan dengan membuang sampah pada tempatnya.

Karakter perilaku peduli lingkungan ini tidak hanya berimbas pada pihak pelopor program Adiwiyata saja, imbas ini disalurkan lewat struktur organisasi yang ditentukan oleh pendidik Adiwiyata dengan pemilihan duta lingkungan di setiap kelas, dari kelas VII-IX, duta lingkungan di SMP Negeri 15 Malang memiliki tugas sebagai perwakilan dari siswa untuk menyambut tamu dari luar dan mengikuti kegiatan-kegiatan diluar sekolah seperti lomba debat dan mading serta terdapat pembagian pokja (kelompok kerja) yang di bentuk agar guru lebih mudah dalam memantau perkembangan penerapan perilaku peduli lingkungan siswa. Fungsi lain Duta lingkungan ini untuk mendampingi teman-temannya agar selalu menerapkan sikap peduli lingkungan sesuai kaidah-kaidah Adiwiyata di SMP Negeri 15 Malang. Pernyataan tersebut releven dengan 
Umala (2016) penanaman pendidikan karakter perlu proses contoh teladan, pembiasaan, dan pembudayaan dalam lingkungan peserta didik dan dalam lingkungan sekolah, keluarga, lingkungan masyarakat, maupun lingkungan media massa.

Hasil wawancara terhadap siswa dan guru pembina Adiwiyata juga menunjukkan bahwa perilaku peduli lingkungan ini tidak hanya diterpakan siswa di dalam lingkungan sekolah, perilaku ini juga diterapkan di luar lingkungan sekolah seperti di rumah dan di jalan. Perilaku peduli lingkungan yang ditunjukkan yaitu dengan merawat kebersihan diri, kebersihan lingkungan, merawat tanaman dan membuang sampah pada tempatnya. Adapun penghambat dalam pelaksanaan program Adiwiyata, pengambat yang nyata dalam penerapannya yaitu dari siswa itu sendiri dalam melaksanakan kegiatan Adiwiyata karena masih terdapat siswa yang kurang kepekaan dalam menyikapi lingkungan hidup di sekitarnya.

Dapat dikatakan bahwa penerapan karakter peduli lingkungan di sekolah dilakukan secara bertahap dan konsisten, kedua cara tersebut dapat mengahasilkan kebiasaan siswa dan secara bertahap menjadi budaya dalam karakter peduli lingkungan siswa.

\section{KESIMPULAN}

Tujuan program Adiwiyata mandiri dalam menanamkan karakter peduli lingkungan siswa SMP Negeri 15 Malang ialah menciptakan pembelajaran yang mampu membentuk siswa agar dapat memahami pembelajaran, norma, dan timbulnya karakter peduli lingkungan. Pelaksanaan program Adiwiyata mandiri, SMP Negeri 15 Malang mengembangkan program Adiwiyata dan memasukan konsep lingkungan kedalam Visi dan Misi sekolah. Implemetasi program Adiwiyata mandiri dalam menanamkan karakter peduli lingkungan siswa SMP Negeri 15 Malang terdapat pada RPP (Rencana Pelaksanaan Pembelajaran) setiap mata pelajaran dengan penerapan teori maupun praktek. Sebagai contoh dalam mata pelajaran IPS terdapat materi Globalisasi dapat disampaikan mengenai teori dan praktek dengan program SMS (Sejenak Memungut Sampah) yang ada di sekitar siswa.

Diketahui dari program implementasi program Adiwiyata mandiri dalam menanamkan karakter peduli lingkungan siswa SMP Negeri 15 Malang disalurkan lewat ekstrakurikuler dan hari wajib Adiwiyata, ada dua esktrakurikuler unggulan yang mengajarkan karakter peduli lingkungan hidup yaitu ektrakurikuler membuat TOMAS (Topeng Limbah Kertas) dan mengolah sampah daun kering menjadi kompos organik. Ekstrakurikuler ini menjadi unggulan karena hasil produksi kedua ekstrakurikuler ini mendapatkan banyak prestasi serta bernilai ekonomi yang menjadi pemasukan kas di sekolah. SMP Negeri 15 Malang memiliki program wajib yaitu Jum'at Adiwiyata yang dilakukan oleh siswa kelas VII-IX dengan wali kelas sebagai pengawas dan pendamping, tugas yang harus dilakukan saat kegiatan Jum'at Adiwiyata adalah membersihkan ventilasi, menyapu, mengepel, mengecek perlengkapan kelas yang sudah habis seperti spidol, menata pojok baca, menyiram tanaman di taman, dan memilah sampah. Sehingga dapat dari berbagai kegiatan di atas dapat menumbuhkan sikap siswa yang bersikap pada ekonomi yang berwawasan lingkungan dan memiliki moralitas tinggi terhadap kepedulian lingkungannya.

Karakter peduli lingkungan siswa SMP Negeri 15 Malang dapat dikatakan berhasil tercapai, dengan proses yang disalurkan lewat sosialisasi kepada seluruh warga sekolah dengan urutan guru pembina Adiwiyata memberikan bimbingan terhadap seluruh siswa duta lingkungan di sekolah melalui praktek ataupun teori dan selanjutnya siswa duta lingkungan menyalurkannya kepada teman-teman sekelas saat program Adiwiyata diterapkan. Hasil ini dapat dilihat dengan banyaknya prestasi yang diperoleh siswa dengan tema lingkungan hidup dan penerapan perilaku peduli lingkungan yang tidak hanya dilakukan di sekolah tetapi juga di luar lingkungan luar sekolah. Dinamika juga ditunjukkan melalui interaksi penerapan karakter peduli lingkungan dari kelas IX-VII, interaksi ditunjukkan dengan kelas IX mengajarkan cara mengolah sampah agar menjadi layak dijual kepada kelas VIII dan kelas VIII menyalurkan pengetahuan tersebut kepada 
kelas VII dan begitupun sebaliknya. Perilaku tersebut dilakukan secara turun temurun di SMP Negeri 15 Malang dan menjadikan karakter peduli lingkungan siswa menjadi semakin nyata dan mengantarkan prestasi terhadap sekolah.

\section{DAFTAR PUSTAKA}

Adam, A. F. (2014). Analisis Implementasi Kebijakan Kurikulum Berbasis Lingkungan Hidup pada Program Adiwiyata Mandiri di SDN Dinoyo Malang. Jurnal Kebijakan dan Pengembangan Pendidikan, 166-168.

Ardianti, S. W. (2017). Peningkatan Perilaku Peduli Lingkungan dan Tanggung Jawab Siswa Melalui Model Ejas Dengan Pendekatan Science Edutaiment. Jurnal Ilmiah "Pendidikan Dasar", 1-2.

Badan Lingkungan Hidup. (2014). Panduan Menuju Adiwiyata Mandiri, pp. 30-32.

Bahrudin, M. D. (2017). Pelaksanaan Program Adiwiyata dalam Mendukung Pembentukkan Karakter Peduli Lingkungan di SMA Negeri 4 Pandeglang. Jurnal Pendidikan Geografi, 2627.

Dinas Pendidikan Kota Malang. (2017). Retrieved from Torehan Prestasi Adiwiyata Mandiri SMP Negeri 15 Malang Dapatkan Apresiasi DLH Tapin Kalsel: https:// diknas.Malangkota.go.id/?p=8616

Hidayatun, N. L. (2016). Studi Deskriptif Pelaksanaan Program Adiwiyata di SD Mubammadiyah Tonggalan Klaten. Jurnal Pendidikan Sekolah Dasar, 1948-1950.

Hidup, K. L. (2009). Tentang Perlindungan dan Pengelolaan Lingkungan Hidup. Retrieved from Undang-Undang No. 32 Tahun 2009: https://www.hukumonline.com/ pusatdata/ downloadfile/ lt4b2885d00d163/parent/lt4b2885a7bc5a d

Ibnu, S. M. (2003). Dasar- dasar Metodologi Penelitian. Malang: Universitas Negeri Malang.

Iswari, D. R. (2017). Evaluasi Penerapan Program Adiwiyata untuk Membentuk Perilaku Peduli Lingkungan. Jurnal Ilmu Lingkungan, 36-
37. Retrieved from https://ejournal. undip.ac.id/ index.php/ilmulingkungan/ article/view/13012

Kementerian Lingkungan Hidup. (2009). Retrieved from Undang-Undang No.32 Tahun 2009 tentang Perlindungan dan Pengelolaan Lingkungan Hidup: https://www. hukumonline. $\quad \mathrm{com} /$ pusatdata/ downloadfile/lt4b2885d00d163/parent/lt 4b2885a7bc5ad

Kementerian Lingkungan Hidup Republik Indonesia. (2013). Retrieved from Pedoman Pelaksanaan Program Adiwiyata. Peraturan Menteri Lingkungan Hidup Republik Indonesia: http://blh.jogjaprov.go.id/pocontent/uploads/Permen-LH-No-05-th2013-Tentang-Pedoman-Adiwiyata.pdf

Keputusan Menteri Pendidikan Nasional Republik Indonesia. (2010). Retrieved from Kesepakatan Nasional Pengembangan Pendidikan Budaya dan Karakter Bangsa: http://sipma.ui.ac.id/files/dokumen/U_P ENDIDIKAN_RISET_P2M/MENDIK BUD_PENDD $\% 20 D A N \% 20 P J /$ Kepme ndiknas $\% 20$ nomor $\% 20045 \% 20$ tahun $\% 20$ 2002\%20Kurikulum\%20Inti\%20PT.pdf.

Landriany, E. (2014). Implementasi Kebijakan Adiwiyata dalam Upaya Mewnjudkan Pendidikan Lingkungan Hidup di SMA Kota Malang. Jurnal Kebijakan dan Pengembangan Pendidikan, 82-88. Retrieved from http://ejournal.umm.ac.id/index/ jmkpp/article/view/1739

Marsanti. (2014). Membangun Karakter Peduli Lingkungan dan Upaya Penyelamatan Lingkungan Hidup. Retrieved from Rakyat Pos: http://www.rakyatpos.com/ membangun-karakter-peduli-lingkungandisekolah-upaya-penyelematanlingkunganhidup.html

Miles, M. (2014). Analisis Data Kualitatif Buku Sumber Tentang Metode-metode Baru. Jakarta: UI Press.

Mumpuni, A. (2016). Muatan Nilai-nilai Karakter pada Buku Teks Kurikulum 2013 Pegangan Guru dan Pegangan Siswa Kelas II. Jurnal Pendidikan Karakter, 18-19. 
Murtilaksono. (2011). Secondary And Higher Education For Development Of In Indonesia. Journal of Development in Sustainable Agricultural, 35-44.

Samani, M. (2012). Konsep dan Model Pendidikan Karakter. Bandung: PT. Remaja Rosdakarya.

Santoso, G. (2007). Metodologi Penelitian Kuantitatif dan Kualitatif. Bandung: PT Remaja Rosdakarya.

Sriyanto. (2007). Kondisi Lingkungan Hidup di Jawa Tengah dan Prospek Pembangunan Ke Depan. Jurnal Geografi, 107-110.

Tim Adiwiyata Tingkat Nasional. (2011). Panduan Adiwiyata Sekolah Peduli Lingkungan dan Berbudaya Lingkungan. Kerjasama Kementerian Lingkungan Hidup dengan Kementerian Pendidikan dan Kebudayaan, pp. 60-62.
Umala, K. (2016). Strategi Internalisasi Karakter Peduli Lingkungan dalam Pembelajaran IPS Terpadu Tema IV Materi Dinamika Interaksi Manusia dengan Lingkungan Pada Siswa Kelas VII di SMPN 1 Kedamen Gresik. Malang: Universitas Maulana Malik Ibrahim.

Vindriyana, R. (2017). Upaya Sekolah dalam Membentuk Sikap Peduli Lingkungan Siswa Melalui Ekestrakurikuler KPLH di SMAN 2 Temanggung. Jurnal Hanata Widya, 29-30.

Yusinta, D. A. (2016). Pengembangan Bahan Ajar Tematik-Integratif Berbasis Nilai Karakter Peduli Lingkungan dan Tanggung Jawab. Jurnal Pendidikan Karakter, 117-118. 